\title{
The Effectiveness of Using Kahoot Media in History Learning at High School
}

\author{
Alifi Nur Prasetia Nugroho \\ Universitas Negeri Yogyakarta \\ Yogyakarta, Indonesia \\ alifinur.pn@uny.ac.id
}

\author{
Ersyah Yulia Nur \\ Universitas Negeri Yogyakarto \\ Yogyakarta, Indonesia \\ ersyah.yulia2015@student.uny.ac.id
}

\begin{abstract}
The purpose of this study are: first, to know the perceptions of the teacher/lecturer about the Kahoot application program in apperception of the teaching and learning process towards indicators of student activity, student and teacher enthusiasm, IT skills, innovative learning, creative in learning, learning effectiveness, and fun learning, secondly the researchers want to know the teacher's perceptions of the Kahoot application program in the apperception of the teaching and learning process towards achievement motivation and thirdly want to know the constraints in using the Kahoot application program in apperception of the teaching and learning process. The methodology in this study used the Descriptive Research method by conducting an experiment using the Kahoot application for high school in Sleman Regency. Based on the results about the perception of the use of the Kahoot program, most of them gave answer that they're Strongly Agree that this program will be implemented by teachers/lecturers.
\end{abstract}

\section{Keywords: Kahoot, History, Effectiveness}

\section{INTRODUCTION}

Today the development of the era of science, digital technology and information demands a lot of changes and adjustments in all fields, including in education world, especially in transferring knowledge to students, both in the classroom and outside the classroom. Especially in the midst of Indonesia's position as the country with the largest number of internet users in ASEAN with a total of 93.4 million or equal to $36 \%$ of the total population in 2015 , even eMarketers said that in 2018 internet users in Indonesia will reach 123 million, this number defeated Japan and made Indonesia included in the Top 5 of the World. In full-length, we can pay attention to data of Internet users from 25 countries or the top 25 countries by internet users.

TABLE. I: THE TOP 25 COUNTRIES BY INTERNET USERS

Top 25 Countries, Ranked by Internet Users, 2014-2018 Millions

\begin{tabular}{|l|l|l|l|l|l|l|}
\hline No & \multicolumn{1}{|c|}{ Negara } & \multicolumn{1}{|c|}{$\mathbf{2 0 1 4}$} & \multicolumn{1}{|c|}{$\mathbf{1 0 1 5}$} & \multicolumn{1}{|c|}{$\mathbf{2 0 1 6}$} & \multicolumn{1}{|c|}{017} & $\mathbf{2 0 1 8}$ \\
\hline $\mathbf{1}$ & China* & 643.6 & 669.8 & 700.1 & 736.2 & 777.0 \\
\hline $\mathbf{2}$ & US** & 252.9 & 259.3 & 264.9 & 269.7 & 274.1 \\
\hline $\mathbf{3}$ & India & 215.6 & 252.3 & 283.8 & 313.8 & 346.3 \\
\hline $\mathbf{4}$ & Brazil & 107.7 & 113.7 & 119.8 & 123.3 & 125.9 \\
\hline $\mathbf{5}$ & Japan & 102.1 & 103.6 & 104.5 & 105.0 & 105.4 \\
\hline $\mathbf{6}$ & Indonesia & 83.7 & 93.4 & 102.8 & 112.6 & 123,0 \\
\hline $\mathbf{7}$ & Russia & 82.9 & 87.3 & 91.4 & 94.3 & 96.6 \\
\hline $\mathbf{8}$ & Germany & 61.6 & 62.2 & 62.6 & 62.7 & 62.7 \\
\hline $\mathbf{9}$ & Mexico & 59.4 & 65.1 & 70.7 & 75.7 & 80.4 \\
\hline
\end{tabular}

\begin{tabular}{|c|c|c|c|c|c|c|}
\hline $\mathbf{1 0}$ & Nigeria & 57.7 & 63.2 & 69.1 & 76.2 & 84.3 \\
\hline 11 & $\mathrm{UK}^{* *} *$ & 50.1 & 51.3 & 52.4 & 53.4 & 54.3 \\
\hline 12 & France & 49.7 & 50.6 & 51.2 & 51.9 & 52.5 \\
\hline 13 & Philippines & 48.0 & 53.7 & 59.1 & 64.6 & 69.3 \\
\hline 14 & Turkey & 41.0 & 44.7 & 47.7 & 50.7 & 53.5 \\
\hline 15 & Vietnam & 40.5 & 44.4 & 48.2 & 52.1 & 56.8 \\
\hline 16 & South Korea & 40.4 & 40.6 & 40.7 & 40.9 & 41.0 \\
\hline 17 & Egypt & 36.0 & 38.3 & 40.9 & 43.9 & 47.4 \\
\hline 18 & Italy & 35.8 & 36.2 & 37.2 & 37.5 & 37.7 \\
\hline 19 & Spain & 31.6 & 32.3 & 33.0 & 33.5 & 33.9 \\
\hline 20 & Canada & 28.3 & 28.8 & 29.4 & 29.9 & 30.4 \\
\hline 21 & Argentina & 27.1 & 29.0 & 29.8 & 30.8 & 31.1 \\
\hline 22 & Colombia & 26.5 & 28.6 & 29.4 & 30.5 & 31.3 \\
\hline 23 & Thailand & 24.3 & 26.0 & 27.6 & 29.1 & 30.6 \\
\hline 24 & Poland & 22.9 & 23.3 & 23.7 & 24.0 & 24.3 \\
\hline 25 & South Africa & 22.7 & 25.0 & 27.2 & 29.2 & 30.9 \\
\hline \multicolumn{2}{|c|}{ Worlwide $* * *$} & 2.89 & 3.07 & 3.24 & 3,41 & 3.60 \\
\hline \multicolumn{7}{|c|}{$\begin{array}{l}\text { Note individual of any age who use the internet from any locatio } \\
\text { via any device at least once per month } \\
\text { *) excludes Hong Kong } \\
\text { **) forecast from Aug } 2014 \\
\text { ***) includes countries not } \\
\text { Source: } \text { eMarkerter Nov } 2014\end{array}$} \\
\hline
\end{tabular}

From the data in the table above, Indonesia as the world's fifth largest internet user, its existent cannot be dammed, from the age of primary education to university students, let alone it is predicted by eMarketer in 2018 Indonesia will defeat Japan. Many factors are very influential on this matter, one of them is the teacher or lecturer factor, and therefore in the book titled Teaching 2030, Barnett Berry says that teachers of the millennium are required to master IT [2].

Globalization is a new era that encourages the development of science and technology. The rapid progress of communication and information technology in this era of globalization is needed by every individual, institution and educational institution to respond to change. The advancement of communication and information technology provides many conveniences in human life including solving educational problems and improving the efficiency and effectiveness of learning in Indonesia. One of them is through the development of learning media programs as stated in Permendikbud No. 22 of 2016 concerning Primary and Secondary Education Process Standards, chapter I, point 13.

The development of learning media programs is intended to produce learning media by utilizing communication and information technology in order to improve the quality of education and equitable 
education. One of the main activities carried out is the development of media programs through audio, video, multi-media and internet for the learning process. According to Law No. 14 of 2005 on Teachers and Lecturers, Article 1 paragraph 1 explains that Teachers are professional educators with the main task of educating, teaching, guiding, directing, training, appraising, and evaluating students in early childhood education in formal education, primary education, and secondary education. Therefore, as an educator and teacher, teachers are required to be able to use learning media. In addition to being able to use existing media, teachers are also required to be able to develop skills to create learning media that are used if the media to explain the material or lessons is not yet available. According to Permendikbud No. 22 of 2016, Chapter IV on Learning Implementation states that the Teacher provides reinforcement and feedback on the responses and learning outcomes of students when the learning process takes place. This means that the learning process ideally takes place in two directions and occurs reciprocally between teachers and students.

However, based on preliminary observations that have been made, the learning process that takes place in high school, especially in History subjects is still uses one-way media such as blackboards and books with the lecture method. There is no appropriate learning media used in accordance with the conditions of the school and students. In addition, the learning atmosphere has not stimulated students to actively participate in the learning process especially in History subjects so that it can hinder the effectiveness of learning. The approaches, strategies, and learning methods used are not yet in accordance with the characteristics of the students. Traits that are reflected by students such as laziness, lack of confidence, do not want to learn etc. This can cause the learning process to be disrupted. Most students also pay less attention to normative adaptive lessons, including history lessons. This is because history lessons are considered a boring and less interesting subject. For this reason, it is needed a learning that uses interactive and interesting media in order to increase students' interest in learning especially in history subjects.

From the above phenomenon, the teacher has a very important role in this matter to be able to develop ideas or notions on how to create an apperception of learning (the initial stage of learning) by utilizing Technological Innovation, by not closing the possibility for those who are still far from the reach of the internet frequency to try to keep up with the times.

\section{METHOD}

This research is primarily aimed at providing a quantitative or descriptive description of a situation objectively. The design of this research is used to solve or answer the problems being faced in the current situation. This research is also intended to explain phenomena or characteristics of individuals, situations or certain groups accurately, in this case about the use of the Game Education Kahoot at the stage of apperception of History learning.

Based on the above objectives, the research method is Descriptive Research by conducting experiments using the Kahoot application for high school teachers and lecturers in Sleman Regency, which at the end of the implementation was asked to perceive the use of the Kahoot application through a questionnaire. The methodology in this study used the Descriptive Research method by conducting an experiment using the Kahoot application for high school teachers and lecturers in Sleman Regency.

\section{RESULT}

Usually most of the teachers and lecturers use the Kahoot education game in the PBM (Teaching and Learning Process) session in the Core Learning stage, with the aim that learning can increase knowledge, skills and attitudes after joining PBM with the Kahoot Education Game. In fact, there are very important things to be considered by the teacher or lecturer before entering the core stage of learning, namely the stage of apperception.

Apperception stage can also be said to be the warm-up stage, where at this stage it can provide reinforcement of the material that has been given at the previous meeting or can also provide material that will be related to the material to be studied while informing the learning objectives to be achieved.

The Kahoot Education Game at this stage is used as an apperception of learning before entering at the core stage of learning. The material in the Kahoot quiz, first looks at the material to be taught or the material that has been taught, then for each question it set the duration and points, if possible to stimulate students, the teacher prepares rewards or prizes for the winner in this Kahoot education games as motivation and appreciation for their achievements.

The results of this research are divided into Teacher Perspective variables about Kahoot application program in the beginning of learning which consists of active, interactive, creative, fun, and learning motivation variables with variable indicators that are actively participating in activities, motivation for achievement, effort to apply and constraint factors.

The results of the questionnaire perceptions of the Kahoot education game application program in the apperception of the teaching and learning process for positive statements can be noted in the following the results of Kahoot implementation in Teaching and Learning Process. Based on the results of the questionnaire given to high school teachers and 
lecturers about the perception of the use of the Kahoot program at the beginning of learning, most of them gave answer that they're Strongly Agree that this program will be implemented by teachers/lecturers. However, there is an important note from the research results that in term of use, a strong internet network is needed to support its implementation; therefore creative ideas must be possessed by teachers/lecturers to create game education in accordance with the situation and conditions in which the teacher/lecturer is in charge

In this research, the researcher also used quantitative descriptive supporting methods using questionnaires as a data collection method where the values listed on the questionnaire indicate that:

TABLE II. SD: STRONGLY DISAGREE HAVE VALUE CRITERIA OF 1, D: DISAGREE HAVE VALUE CRITERIA OF 2, N: NEUTRAL, HAVE VALUE CRITERIA OF 3, A: AGREE HAVE VALUE CRITERIA OF 4, SA: STRONGLY AGREE, HAVE VALUE CRITERIA OF 5

\begin{tabular}{lccc}
\hline \multicolumn{3}{c}{ Kahoot Implementation } & $\begin{array}{c}\text { Std. } \\
\text { Deviati } \\
\end{array}$ \\
& Mean & on & Variance \\
\hline Interesting & 4,47 & 0,563 & 0,316 \\
Not Boring & 4,13 & 0,864 & 0,746 \\
Easy to use & 4,39 & 0,704 & 0,496 \\
The network must be & 4,22 & 0,806 & 0,650 \\
strong & & & \\
Interactive & 4,28 & 0,654 & 0,428 \\
Innovative & 4,28 & 0,826 & 0,682 \\
Giving Skills & 4,20 & 0,694 & 0,482 \\
Giving encouragement & 4,17 & 0,767 & 0,589 \\
Effective & 4,17 & 0,788 & 0,621 \\
Fun & 4,22 & 0,701 & 0,491 \\
Make student creative & 4,27 & 0,718 & 0,516 \\
Smooth process & 4,16 & 0,781 & 0,610 \\
Valid N (listwise) & & 64 & \\
& & & \\
\hline
\end{tabular}

After collecting data at the research location with the random sampling method, the data obtained from the results of filling out the online questionnaire were 37 respondents and 27 questionnaires for manual filling so that a total of 64 respondents consisted of students and teachers. The results of data processing using SPSS analysis as follows:

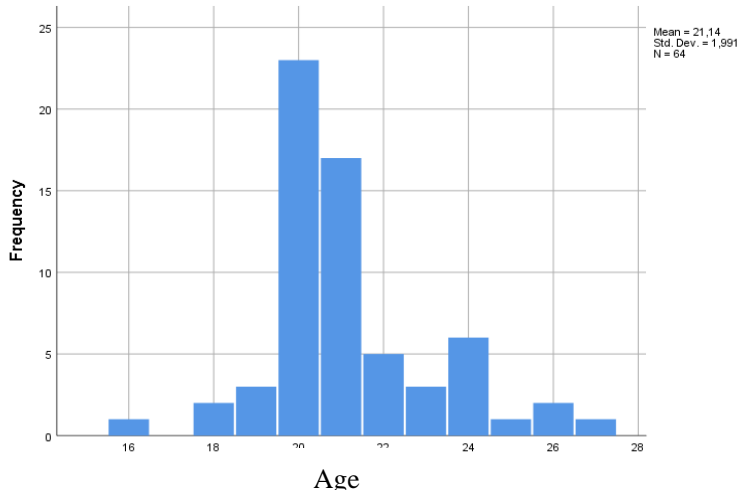

Fig. 1. The average age of the respondents
Based on the graph of the age of museum visitors, visitors are in the age range of 16 to 27 years old. The average visitor with the most frequency is visitors aged 20 and 21 years old.

TABLE. III. RESULTS OF KAHOOT IMPLEMENTATION

\begin{tabular}{lccc}
\hline & \multicolumn{2}{c}{ Kahoot Implementation } & \\
& Mean & Std. Deviation & Variance \\
\hline Interesting & 4,47 & 0,563 & 0,316 \\
Not boring & 4,13 & 0,864 & 0,746 \\
Easy to use & 4,39 & 0,704 & 0,496 \\
Strong network & 4,22 & 0,806 & 0,650 \\
Interactive & 4,28 & 0,654 & 0,428 \\
Innovative & 4,28 & 0,826 & 0,682 \\
Skills & 4,20 & 0,694 & 0,482 \\
encouragement & 4,17 & 0,767 & 0,589 \\
Effective & 4,17 & 0,788 & 0,621 \\
Fun & 4,22 & 0,701 & 0,491 \\
creative & 4,27 & 0,718 & 0,516 \\
Smooth & 4,16 & 0,781 & 0,610 \\
process & & & \\
Valid N & & & \\
(listwise) & & & \\
\hline
\end{tabular}

The table is an analysis of the use of Kahoot implementation in Senior High Schools offered by researchers as a problem-solving effort. 64 respondents agreed that Kahoot was very fun. It is known from the results of descriptive analysis which shows that the average respondent agrees to learning using Kahoot with a mean value of more than 4 . Based on the results of analysis of the data obtained from the questionnaire it can be drawn a red thread that parallel learning using Kahoot provides effectiveness and fun feeling in studying history.

\section{IV.DISCUSSION}

In the Kahoot application program it also provides input for teachers and lecturers to be more enthusiastic in preparing material and adding skills in using the internet or IT, this is what will encourage teachers and lecturers to become teachers who innovate in giving material to their students, because so far psychologically the student in carrying out learning in school especially in history subjects tends to have "boring" characterization, therefore innovating in learning is very important so that the learning objectives are achieved. This is supported by the results of teachers and lecturers' perceptions of enthusiasm, IT skills, and innovation in learning, stated that most of them strongly agree that this needs to be done by teachers and lecturers. This is also in accordance with the opinion of Barnett Berry who said that educators in 2030 must master IT [2].

Creative teachers can be ascertained to have a lot of ideas or notions, in the Kahoot application program, creative teachers are needed to create how to package game education that has something to do with the material that will be given or strengthen the material that has been provided, so that learning using education games is effective and becomes capital for 
students to understand the material or strengthen the material that has been received. With fun learning, it makes students active, not bored and supported by creative ideas of teachers and lecturers in using IT, it will be a high motivation for students to be achievers, enthusiasm for learning and focus on participating in PBM, this can be done by all teachers and lecturers by always creating creative learning with various ideas or ideas tailored to the situation and environmental conditions in which they are assigned.

Furthermore, in this discussion, it is important to know that the use of the Kahoot program application requires a strong internet network owned by the school or campus and internet quota for students and supporting tools (Computers and handphone) so that there are no hinder in learning activities. Therefore, if the situation is supportive, then learning activities using game education with the Kahoot application program can be implemented. However, if the situation is not supportive, the teacher and lecturer need a creative idea by paying attention to the situation and conditions; this is usually the inhibiting factor for the teacher or lecturer who is not creative.

\section{CONCLUSIONS}

Based on the results of the research and discussion above, it can be concluded that:

1. Teachers and lecturers' perceptions state that the level of activity of students in the beginning of learning becomes all active.

2. The enthusiasm of the teacher in the learning process is said to be very enthusiastic.

3. Still in the Kahoot application program a teacher who masters IT is needed

4. The learning model using the Kahoot application program in History learning can be categorized as a learning innovation.

5. It takes teachers who have creative nature to create interesting learning

6. Learning by using the Kahoot education game application program is very effective

7. Learning by using the Kahoot education game application program is very fun.

\section{REFERENCES}

[1] Andang Ismail "Education Games," Yogyakarta: Pilar Media, 2006.

[2] Barnett Berry "Teaching 2030" Amerika Serikat : Teacher College Press, 2011

[3] Dahlan Y al-Barry L. Lya Sofyan Yakub. "Kamus Induk Istilah Ilmiah, ” Surabaya:Target Press, 2000.

[4] H.Abu Ahmadi dan Munawar Sholeh "Psikologi Perkembangan” Jakarta: Asdi Mahasatya, 2005.

[5] Imam Bawani "Perkembangan Jiwa" Surabaya: Bina Ilmu, 1997

[6] John M.Echols dan Hassan Shadily "Kamus Inggris Indonesia” Jakarta: Gramedia, 1996 